\title{
Banana Flavor
}

National Cancer Institute

\section{Source}

National Cancer Institute. Banana Flavor. NCI Thesaurus. Code C73364.

A characteristic of a medicinal product, specifying that its most predominant agreeable savor detected by the unified sensation of taste and olfactory receptors resembles banana. 